\section{A Forced Ventilation Micropropagation System for Photoautotrophic Production of Sweetpotato Plug Plantlets in a Scaled-up Culture Vessel: II. Carbohydrate Status}

\author{
Sandra B. Wilson, ${ }^{1}$ \\ Jeongwook Heo, ${ }^{2}$ \\ Chieri Kubota, ${ }^{3}$ and \\ Toyoki Kozai ${ }^{3}$
}

ADDITIONAL INDEX WORDS. air distribution system, Ipomoea batatas, plant tissue culture, soluble sugars, starch, net photosynthetic rate

Summary. Sweetpotato [Ipomoea batatas (L.) Lam., 'Beniazuma'] plantlets were grown photoautotrophically (without sugar) for 12 days in an improved forced ventilation system designed with air distribution pipes for uniform spatial distributions of carbon dioxide $\left(\mathrm{CO}_{2}\right)$ concentration. Enriched $\mathrm{CO}_{2}$ conditions and photosynthetic photon flux (PPF) were provided at $1500 \mu \mathrm{mol} \cdot \mathrm{mol}^{-1}$

\footnotetext{
The authors are thankful to The Japanese Society for the Promotion of Sciences for sponsoring the senior author and J. Albano and M. Tignor for their critical reading of the manuscript. The cost of publishing this paper was defrayed in part by the payment of page charges. Under postal regulations, this paper therefore must be hereby marked advertisement solely to indicate this fact.

${ }^{1}$ Department of Environmental Horticulture, Indian River Research and Education Center, University of Florida, 2199 South Rock Road, Fort Pierce, FL 34945 .

${ }^{2}$ Research Center for the Development of Advanced Horticultural Technology, Department of Horticulture, Chungbuk National University, Cheongju, Chungbuk, 361-763, Korea.

${ }^{3}$ Department of Bioproduction Science, Faculty of Horticulture, Chiba University, Matsudo, Chiba 271 8510, Japan.
}

and $150 \mu \mathrm{mol} \cdot \mathrm{m}^{-2} \cdot \mathrm{s}^{-1}$, respectively. The forced $(\mathrm{F})$ ventilation treatments were designated high $(\mathrm{FH})$, medium (FM), and low (FL), corresponding to ventilation rates of $23 \mathrm{~mL} \cdot \mathrm{s}^{-1}(1.40$ inch $\left.^{3} / \mathrm{s}\right), 17 \mathrm{~mL} \cdot \mathrm{s}^{-1}\left(1.04 \mathrm{inch}^{3} / \mathrm{s}\right)$, and $10 \mathrm{~mL} \cdot \mathrm{s}^{-1}\left(0.61 \mathrm{inch}^{3} / \mathrm{s}\right)$, respectively, on day 12. The natural $(\mathrm{N})$ ventilation treatment was extremely low $(\mathrm{NE})$ at $0.4 \mathrm{~mL} \cdot \mathrm{s}^{-1}\left(0.02 \mathrm{inch}^{3} /\right.$ $s)$, relative to the forced ventilation treatments. Total soluble sugar (TSS) and starch content were determined on day 12. Total soluble sugars (sucrose, glucose, fructose) of $\mathrm{FH}$ plantlets were lowest in leaf tissue and highest in stem tissue as compared to other ventilation treatments. Starch concentration was higher in leaf tissue of $\mathrm{FH}$ or FM plantlets as compared to that of FL or NE plantlets. Plantlets subjected to FH or FM treatments exhibited significantly higher net photosynthetic rates (NPR) than those of the other treatments; and on day 12, NPR was almost five times higher in the FH or FM treatment than the FL or NE treatments. Carbohydrate concentration of plantlets was also influenced by the position of the plantlets in the vessel. Within the forced ventilation vessels, leaf TSS of FH and FM plantlets was similar regardless of whether plantlets were located near the inlet or outlet of $\mathrm{CO}$ enriched air. However, under $\mathrm{FH}$ or FM conditions, leaf starch concentration was higher in plantlets located closest to the $\mathrm{CO}_{2}$ inlet as compared to the outlet.

I n commercial, mass micropropagation of photomixotrophic (sucrose in the medium) plantlets, low growth rates, low ex-vitro survival percentages of plantlets, and high contamination risks are regularly observed. Sucrose is commonly provided in the tissue culture medium as an energy source. Therefore, photomixotrophic plantlets often suffer from increased chances of pathogen contamination and decreased survival percentages during acclimatization once transferred to greenhouse conditions (Kozai et al., 1997). In addition, plantlets grown in culture vessels are characterized by low net photosynthetic rates caused by low $\mathrm{CO}_{2}$ concentrations in the vessels during the photoperiod and low light intensities typical of culture rooms (Fujiwara et al., 1987; Heo and Kozai, 1999).

Successful photoautotrophic systems (no sucrose in the medium) have been developed for enhancing photo- synthesis and growth of the plantlets by increasing $\mathrm{CO}_{2}$ concentration and light intensity in the culture vessel (Kozai et al., 1988). Photoautotrophic systems also have a reduced potential of contamination, which facilitates success of large-scale operations. Recently, forced ventilation culture systems have been developed for large-scale photoautotrophic micropropagation (Heo and Kozai, 1999) that have improved plant uniformity (Heo et al., 2000), and that have a circulating nutrient supply system (Zobayed et al., 1999). Plantlets grown in these systems have been well characterized for many growth and developmental parameters such as fresh and dry weight, chlorophyll concentration, cuticular development, and stomatal functioning (Heo et al., 2000; Zobayed et al., 1999). However, there have been no investigations looking at the carbohydrate status of the plants in forced ventilation systems, although carbohydrate status is considered to be highly correlated with the ex-vitro establishment as indicated by Piqueras et al. (1998) and Wilson et al. (1998, 2000). Depending on the plant species and in vitro culture procedure, source-sink transitions are altered during in vitro growth and ex vitro acclimatization (Van Huylenbroeck et al., 1998). Physiological understanding of the carbohydrate status is useful for predicting plantlet growth and acclimatization to greenhouse conditions.

The objective of this study was to characterize the carbohydrate status of plantlets grown in an improved forced ventilation system.

\section{Materials and methods}

Plant material and CULTURE CONDITIONS. Detailed culture methods and conditions were previously described (Heo et al., 2000) and will be omitted. In summary, single-node, single-leaf stem cuttings were excised from sweetpotato plantlets (maintained photomixotrophically with $20 \mathrm{~g} \cdot \mathrm{L}^{-1}$ $(2.73 \mathrm{oz} / \mathrm{gal})$ sucrose in the medium $)$ and cultured photoautotrophically (no sugar in the medium) on Florialite supporting material (Nisshinbo Industries, Inc., Tokyo, Japan) in Murashige and Skoog (1962) liquid medium. Plantlets were grown for 12 days in a culture room where air temperature and relative humidity were maintained at $29 / 26 \pm 0.5{ }^{\circ} \mathrm{C}\left(84 / 79 \pm 2{ }^{\circ} \mathrm{F}\right)$ (photo-/dark period) and $80 \% \pm 5 \%$, 
Table 1. Number of air exchanges in culture vessels and net photosynthetic rates (NPR) of sweetpotato plantlets grown photoautotrophically for $12 \mathrm{~d}$ at $1500 \mu \mathrm{mol} \cdot \mathrm{mol}^{-1} \mathrm{CO}_{2}$ and $150 \mu \mathrm{mol} \cdot \mathrm{m}^{-2} \cdot \mathrm{s}^{-1} \mathrm{PPF}$. Means \pm standard error are shown. FH = high forced ventilation rate $\left(23 \mathrm{~mL} \cdot \mathrm{s}^{-1}\right)^{\mathrm{z}}, \mathrm{FM}=$ medium forced ventilation rate $\left(17 \mathrm{~mL} \cdot \mathrm{s}^{-1}\right), F L=10 w$ forced ventilation rate $\left(10 \mathrm{~mL} \cdot \mathrm{s}^{-1}\right)$, and $\mathrm{NE}=$ extremely low natural ventilation rate $\left(0.4 \mathrm{~mL} \cdot \mathrm{s}^{-1}\right)$.

\begin{tabular}{lcc}
\hline $\begin{array}{l}\text { Treatment } \\
\text { code }\end{array}$ & $\begin{array}{c}\text { Air exchanges } \\
(\mathbf{n o} . / \mathbf{h})\end{array}$ & $\begin{array}{c}\text { NPR } \\
\left(\mu \mathbf{m o l}^{-\mathbf{1}} \mathbf{C O}_{\mathbf{2}} \text { per } \text { plantlet }\right)\end{array}$ \\
\hline FH & 7.4 & $12.65 \pm 0.99$ \\
FM & 5.5 & $12.29 \pm 0.46$ \\
FL & 3.2 & $4.22 \pm 0.46$ \\
NE & 3.0 & $2.6 \pm 0.02$ \\
\hline
\end{tabular}

${ }^{\mathrm{z}} 16.4 \mathrm{~mL} \cdot \mathrm{s}^{-1}=1.0 \mathrm{inch}^{3} / \mathrm{s}$. respectively. Enriched $\mathrm{CO}_{2}$ conditions and $P P F$ were provided at 1500 $\mu \mathrm{mol} \cdot \mathrm{mol}^{-1}$ and $150 \mu \mathrm{mol} \cdot \mathrm{m}^{-2} \cdot \mathrm{s}^{-1}$, respectively.

FORCED AND NATURAL VENTILATION SYSTEMS. Detailed design of the forced ventilation system was previously described (Heo et al., 2000) and will be omitted. In summary, the forced ventilation micropropagation system consisted of a scaled-up culture vessel [11.14 L (2.94 gal)], air distribution pipes, an air flow rate meter, and an air pump for supplying $\mathrm{CO}_{2}$-enriched air. The natural ventilation system consisted of a polycarbonate, cylindrical vessel ( $100 \mathrm{~mm}$ (3.9 inches) high by $80 \mathrm{~mm}$ (3.2 inches) wide, $0.48 \mathrm{~L}$ (16.2 $\mathrm{fl} \mathrm{oz})$ ) with three air diffusive filters located on the lid. Forced ventilation in the large culture vessels was adjusted at high $\left(23 \mathrm{~mL} \cdot \mathrm{s}^{-1}\right.$, FH treatment), medium (17 $\mathrm{mL} \cdot \mathrm{s}^{-1}, \mathrm{FM}$ treatment) and low $\left(10 \mathrm{~mL} \cdot \mathrm{s}^{-1}\right.$, FL treatment $)$ rates while that of naturally ventilated vessels remained at $0.4 \mathrm{~mL} \cdot \mathrm{s}^{-1}$ (NE treatment).

Net photosynthetic rate. Net photosynthetic rate per plantlet $\left(\mathrm{P}_{\text {, }}\right.$, $\mu \mathrm{mol} \cdot \mathrm{h}^{-1} \mathrm{CO}_{2}$ ) on day 12 in $\mathrm{FH}, \mathrm{FM}$, and $\mathrm{FL}$ was estimated by using the following equation (Fujiwara et al., 1987): $\mathrm{P}_{\mathrm{n}}=k \cdot \mathrm{V}_{\mathrm{r}} \cdot d C / \mathrm{n}(k$ : conversion factor $\left(\mathrm{mol}^{\mathrm{r}} \cdot \mathrm{m}^{-3}\right), \mathrm{V}$ : ventilation rate per vessel $\left(\mathrm{mL} \cdot \mathrm{h}^{-1}\right), d C$ : difference in $\mathrm{CO}_{2}$ concentration between the air inlet and outlet of forced ventilated vessel or between the air outside and inside of the naturally ventilated vessel, n: number of plantlets per vessel).

PLANT CARBOHYDRATE anAlysis. At day 12 , leaves, stems, and roots were frozen in liquid $\mathrm{N}_{2}$ and freeze-dried. To obtain sufficient tissue for carbohydrate analysis, four adjoining plantlets (inside the vessel) were pooled to generate a sample. Six samples were analyzed for each vessel. The procedures for soluble sugar extraction were modi- fied as previously described (Boersig and Negm, 1985; Miller and Langhans, 1989). Leaves, stems, and roots were ground separately. A known amount [30 to $50 \mathrm{mg}(0.001$ to $0.002 \mathrm{oz})]$ of tissue was loaded into glass Pasteur pipettes with glass wool plugs $(1 \mathrm{~cm}$, 0.39 inches) and extracted three times with $1.5 \mathrm{~mL}$ of 12 methanol : 5 chloroform: 3 water (by volume, MCW). $100 \mu \mathrm{L}$ sorbitol $\left(10 \mathrm{~g} \cdot \mathrm{L}^{-1}\right)$ was added as an internal standard. Distilled water $(3.5 \mathrm{~mL})$ was added to samples and the aqueous phase was removed and applied to polyethylene columns con- taining $3 \mathrm{~mL} 1$ methanol : 1 water (v:v, $\mathrm{MW}$ ) and cation and anion resin ( $1 \mathrm{~mL}$ Amberlite IRA-45 layered with $1 \mathrm{~mL}$ Dowex 50-W, Sigma-Aldrich Co.,St. Louis, Mo.). Soluble carbohydrates were eluted twice with $1 \mathrm{~mL} \mathrm{MW}$ and evaporated to dryness using a rotary flash evaporator. The dry residue was resuspended in $1 \mathrm{~mL}$ HPLC-grade water and filtered through a $0.45 \mu \mathrm{m}$ membrane before HPLC injection. Sucrose, glucose, and fructose were separated and detected using an HPLC with a refractive index detector (Hitachi Ltd., Tokyo, Japan) and a Gelpack GL-C61l column (Hitachi Chemical Co., Tokyo, Japan) that was maintained at $70^{\circ} \mathrm{C}\left(158^{\circ} \mathrm{F}\right)$. The component analysis was determined using a D-2000 Chromato-Integrator (Hitachi Ltd., Tokyo, Japan) and then regression equations describing the sucrose, glucose, and fructose calibration lines were calculated. Total soluble sugars were calculated by combining the sucrose, glucose, and fructose concentrations.

The procedures for starch determination were modified as described by Haissig and Dickson (1979) and
Table 2. Total soluble sugar (TSS) concentration of sweetpotato plantlets grown photoautotrophically for $12 \mathrm{~d}$ at $1500 \mu \mathrm{mol} \cdot \mathrm{mol}^{-1} \mathrm{CO}_{2}$ and 150 $\mu \mathrm{mol} \cdot \mathrm{m}^{-2} \cdot \mathrm{s}^{-1} P P F$. Means \pm standard error are shown. $\mathrm{FH}=\mathbf{h i g h}$ forced ventilation rate $\left(23 \mathrm{~mL} \cdot \mathrm{s}^{-1}\right)^{\mathrm{z}}, \mathbf{F M}=$ medium forced ventilation rate $\left(17 \mathrm{~mL} \cdot \mathrm{s}^{-1}\right)$, $\mathrm{FL}=$ low forced ventilation rate $\left(10 \mathrm{~mL} \cdot \mathrm{s}^{-1}\right)$, and $\mathrm{NE}=$ extremely low natural ventilation rate $\left(0.4 \mathrm{~mL} \cdot \mathrm{s}^{-1}\right)$.

\begin{tabular}{lccc}
\hline $\begin{array}{l}\text { Treatment } \\
\text { code }\end{array}$ & $\begin{array}{c}\text { Leaf } \\
\left(\mathbf{m g} \cdot \mathbf{g}^{-\mathbf{1}} \mathbf{D W}\right)^{\mathbf{y x}}\end{array}$ & $\begin{array}{c}\text { Stem } \\
\left(\mathbf{m g} \cdot \mathbf{g}^{-\mathbf{1}} \mathbf{D W}\right)\end{array}$ & $\begin{array}{c}\text { Root } \\
\left(\mathbf{m g} \cdot \mathbf{g}^{-1} \mathbf{D W}\right)\end{array}$ \\
\hline FH & $27.01 \pm 3.98$ & $60.21 \pm 10.44$ & $26.41 \pm 5.05$ \\
FM & $36.35 \pm 3.80$ & $41.16 \pm 3.49$ & $28.31 \pm 3.24$ \\
FL & $39.81 \pm 3.10$ & $24.47 \pm 3.80$ & $11.57 \pm 1.12$ \\
NE & $33.47 \pm 3.30$ & $42.62 \pm 9.03$ & $19.65 \pm 2.93$ \\
\hline
\end{tabular}

${ }^{2} 16.4 \mathrm{~mL} \cdot \mathrm{s}^{-1}=1.0 \mathrm{inch}^{3} / \mathrm{s}$.

${ }^{y} 1.0 \mathrm{mg} \cdot \mathrm{g}^{-1}=0.1 \%$.

${ }^{\mathrm{x}} \mathrm{DW}=\mathrm{dry}$ weight.

Table 3. Starch concentration of sweetpotato plantlets grown photoautotrophically for $12 \mathrm{~d}$ at $1500 \mu \mathrm{mol} \cdot \mathrm{mol}^{-1} \mathrm{CO}_{2}$ and $150 \mu \mathrm{mol} \cdot \mathrm{m}^{-2} \cdot \mathrm{s}^{-1}$ PPF. Means \pm standard error are shown. $F H=$ high forced ventilation rate $\left(23 \mathrm{~mL} \cdot \mathrm{s}^{-1}\right)^{\mathrm{z}}, \mathbf{F M}=$ medium forced ventilation rate $\left(17 \mathrm{~mL} \cdot \mathrm{s}^{-1}\right), \mathrm{FL}=1 \mathrm{ow}$ forced ventilation rate $\left(10 \mathrm{~mL} \cdot \mathrm{s}^{-1}\right)$, and $\mathrm{NE}=$ extremely low natural ventilation rate $\left(0.4 \mathrm{~mL} \cdot \mathrm{s}^{-1}\right)$.

\begin{tabular}{lccc}
\hline $\begin{array}{l}\text { Treatment } \\
\text { code }\end{array}$ & $\begin{array}{c}\text { Leaf } \\
\left(\mathbf{m g} \cdot \mathbf{g}^{-1} \mathbf{D W}\right)\end{array}$ & $\begin{array}{c}\text { Stem } \\
\left(\mathbf{m g} \cdot \mathbf{g}^{-1} \mathbf{D W}\right)\end{array}$ & $\begin{array}{c}\text { Root } \\
\left(\mathbf{m g} \cdot \mathbf{g}^{-1} \mathbf{D W}\right)\end{array}$ \\
\hline FH & $35.99 \pm 5.89$ & $11.38 \pm 0.79$ & $2.33 \pm 0.35$ \\
FM & $40.12 \pm 4.71$ & $14.44 \pm 1.75$ & $2.41 \pm 0.15$ \\
FL & $17.77 \pm 1.58$ & $6.36 \pm 0.76$ & $3.35 \pm 0.57$ \\
NE & $14.57 \pm 1.05$ & $13.78 \pm 1.12$ & $4.88 \pm 0.16$
\end{tabular}

${ }^{\mathrm{z}} 16.4 \mathrm{~mL} \cdot \mathrm{s}^{-1}=1.0 \mathrm{inch}^{3} / \mathrm{s}$

${ }^{\mathrm{y}} 1.0 \mathrm{mg} \cdot \mathrm{g}^{-1}=0.1 \%$.

${ }^{\mathrm{x} D W}=$ dry weight. 

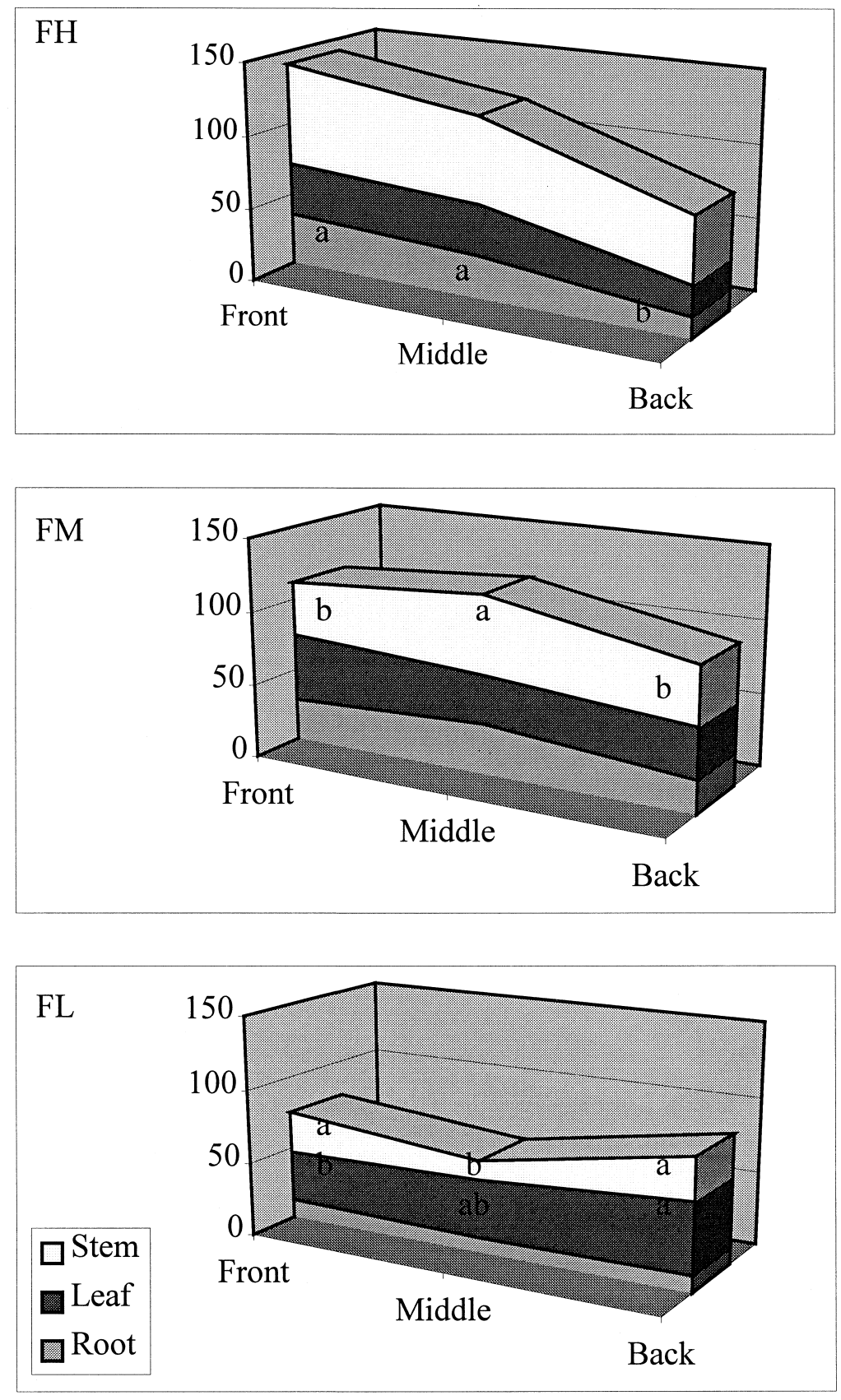

Location of plants in vessel

Fig. 1. Total soluble sugar (TSS) concentration of sweetpotato plantlets grown photoautotrophically for $12 \mathrm{~d}$ at $1500 \mu \mathrm{mol} \cdot \mathrm{mol}^{-1} \mathrm{CO}_{2}$ and $150 \mu \mathrm{mol} \cdot \mathrm{m}^{-2} \cdot \mathrm{s}^{-1}$ $P P F$. TSS was measured in plantlets located within the front, middle and back of the forced ventilated vessels, whereby front indicates location of $\mathrm{CO}_{2}$ inlet and back indicates location of $\mathrm{CO}_{2}$ outlet. $\mathrm{FH}=$ high forced ventilation rate (23 $\left.\mathrm{mL} \cdot \mathrm{s}^{-1}\right), \mathrm{FM}=$ medium forced ventilation rate $\left(17 \mathrm{~mL} \cdot \mathrm{s}^{-1}\right)$, and $\mathrm{FL}=1$ low forced ventilation rate $\left(10 \mathrm{~mL} \cdot \mathrm{s}^{-1}\right)$. Mean separation by $\mathrm{LSD}$ at $\alpha=0.05 ; 16.4 \mathrm{~mL} \cdot \mathrm{s}^{-1}=$ $1.0 \mathrm{inch}^{3} / \mathrm{s}, 1.0 \mathrm{mg} \cdot \mathrm{g}^{-1}=0.1 \%$.

Miller and Langhans (1989). The tissue residue left in the pasteur pipets following soluble sugar extraction was dried overnight at $60^{\circ} \mathrm{C}\left(140{ }^{\circ} \mathrm{F}\right)$, suspended in $4 \mathrm{~mL} \mathrm{Na}$-acetate buffer (100 mM, pH 4.5) and placed in a boiling water bath for $20 \mathrm{~min}$. After cooling to room temperature, $1.0 \mathrm{~mL}$ amyloglucosidase solution (from $A s^{-}$ pergillus niger Tiegh., Sigma-Aldrich Co., St. Louis, Mo.) (50 units/assay in $0.1 \mathrm{M} \mathrm{pH} 4.2 \mathrm{Na}$-acetate buffer) was added to each test tube. Samples were incubated for $48 \mathrm{~h}$ at $55^{\circ} \mathrm{C}\left(131^{\circ} \mathrm{F}\right)$ with occasional agitation. Glucose determination via a glucose oxidase and peroxidase enzymatic method was completed on a $100-\mu \mathrm{L}$ sample. Absorbance was determined at $450 \mathrm{~nm}$ on a spectrophotometer and starch content was calculated based on the regression equation describing the glucose calibration line $(0.0$ to $0.5 \mu \mathrm{mol})$.

EXPERIMENTAL DESIGN AND STATISTICAL ANALYSIS. Uniformity data of forced ventilation systems were subjected to ANOVA with means separation by LSD test at $\alpha=0.05$. The nature of the experimental design did not allow for randomized vessels or an equal number of samples between forced and natural ventilation treatments. Therefore, standard errors $( \pm \mathrm{l})$ were calculated among treatments and used to detect differences between treatments.

\section{Results and discussion}

Net photosynthetic rate. The number of air exchanges per hour was about 2.4 times more in the $\mathrm{FH}$ vessel than in the FL or NE vessel (Table 1 ). FL and NE vessels had similar hourly air exchange rates. Plantlets subjected to the FH or FM treatment exhibited significantly higher NPR than those of the other treatments, and on day 12 , NPR was almost five times higher in the FH or FM treatments than in the NE treatment and about three times higher than in the FL treatment (Table 1). Heo and Kozai (1999) showed that the NPR of sweetpotato plug plantlets in vitro was 30 to 40 times greater in a forced ventilation micropropagation system containing no-sugar compared with a conventional micropropagation system containing sugar. Low NPR has been correlated with low $\mathrm{CO}_{2}$ concentrations inside the vessels (Fujiwara et al. 1988; Kozai and Iwanami, 1988; Zobayed et al., 1999) caused mainly by a lower number of air exchanges per hour (Kozai et al., 1986). Throughout the culture period, the $\mathrm{CO}_{2}$ concentration inside the culture vessel during the photoperiod was more than 350 $\mu \mathrm{mol} \cdot \mathrm{mol}^{-1}$ lower in the NE treatment than in the FH, FM, and FL treatments (Heo et al., 2000).

CARBOHYDRATE ANALYSIS. Leaf TSS (sucrose, glucose, and fructose) and starch concentration of plantlets grown for $12 \mathrm{~d}$ with $\mathrm{FH}$ or FM ventilation were two to three times more than that of plantlets on day 0 (in vitro stock 

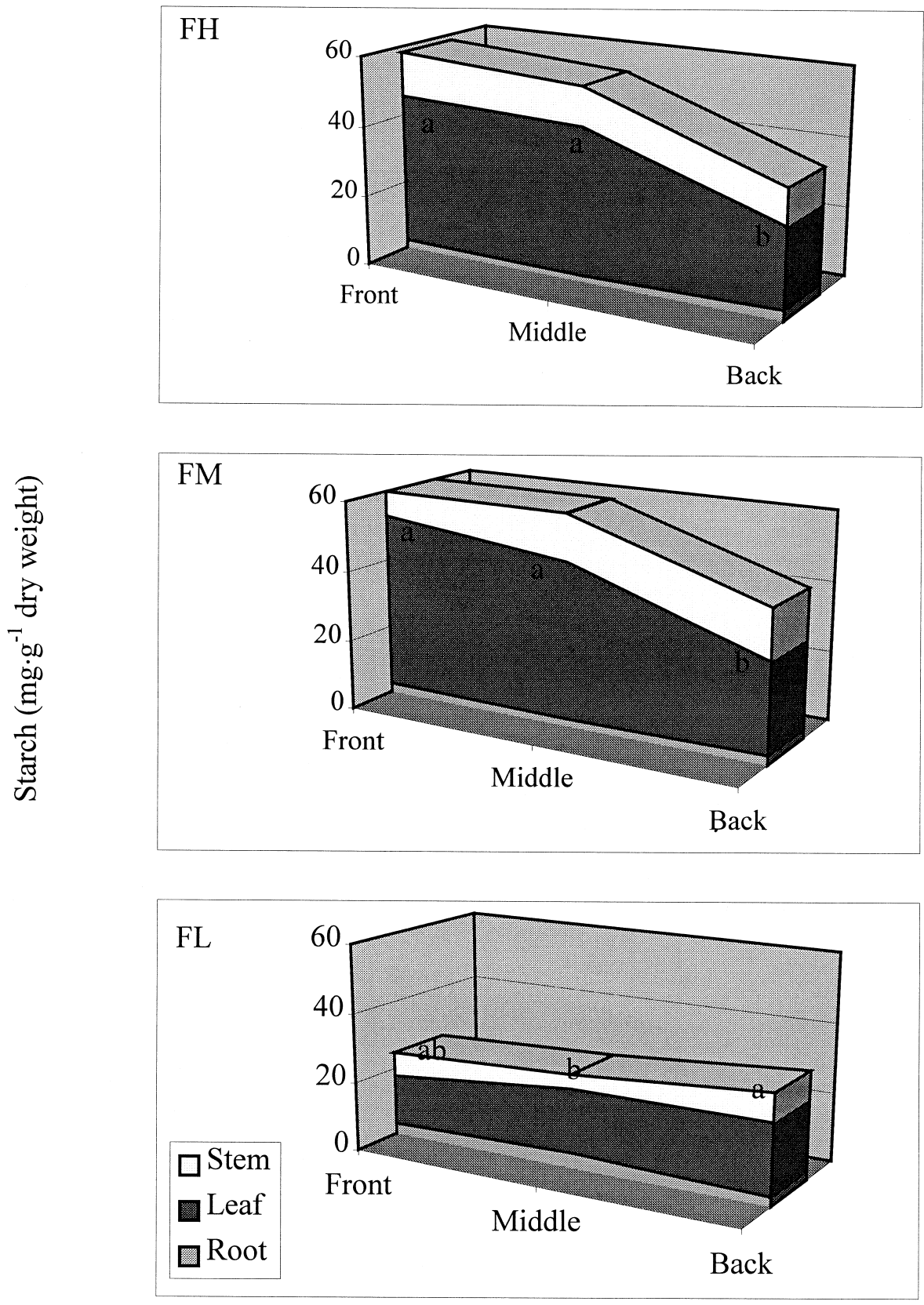

Location of plants in vessel

Fig. 2. Starch concentration of sweetpotato plantlets grown photoautotrophically for $12 \mathrm{~d}$ at $1500 \mu \mathrm{mol} \cdot \mathrm{mol}^{-1} \mathrm{CO}_{2}$ and $150 \mu \mathrm{mol} \cdot \mathrm{m}^{-2} \cdot \mathrm{s}^{-1} \mathrm{PPF}$. Starch was measured in plantlets located within the front, middle and back of the forced ventilated vessels, whereby front indicates location of $\mathrm{CO}_{2}$ inlet and back indicates location of $\mathrm{CO}_{2}$ outlet. $\mathrm{FH}=$ high forced ventilation rate $\left(23 \mathrm{~mL} \cdot \mathrm{s}^{-1}\right)$, FM = medium forced ventilation rate $\left(17 \mathrm{~mL} \cdot \mathrm{s}^{-1}\right)$, and $F L=10 w$ forced ventilation rate $\left(10 \mathrm{~mL} \cdot \mathrm{s}^{-1}\right)$. Mean separation by $\mathrm{LSD}$ at $\alpha=0.05 ; 16.4 \mathrm{~mL} \cdot \mathrm{s}^{-1}=1.0$ inch $^{3} / \mathrm{s}, 1.0 \mathrm{mg}^{-1}=0.1 \%$.

plantlets grown photomixotrophically) (data not presented). The strong carbohydrate increase observed in in-vitroformed leaves $12 \mathrm{~d}$ after transfer suggests that newly formed in vitro leaves are photosynthetically capable with presumably normal source-sink transitions. Leaf TSS concentration was lower in $\mathrm{FH}$ plantlets as compared to FL, FM, or NE ventilation treatments (Table 2). Reduced leaf TSS of FH plantlets correlated with increased stem TSS. Van Huylenbroeck et al. (1998) attributed low sucrose content and no accumulation of starch in micropropagated calathea (Calathea louisae Gagnep.) leaves to high carbohydrate export to other sinks. Plantlets grown with low forced ventilation had almost 1.5 times greater leaf TSS but almost 2.5 times less stem or root TSS as compared to $\mathrm{FH}$ plantlets.

FH and FM plantlets had similarly higher leaf and lower root starch concentrations than FL and NE plantlets. Plantlets grown with natural ventilation had low leaf starch concentration and high root starch concentration as compared to plantlets grown with high, medium, or low forced ventilation (Table 3). Lower leaf starch of NE plantlets correlated with slower growth and development of plantlets since the photoautotrophic growth of plantlets was greater with the forced ventilation system than with the natural ventilation system (Heo et al., 2000). Deng and Donnelly (1993) correlated increased growth of in vitro red raspberry (Rubus idaeus L.) with high photosynthetic ability. Low leaf starch of NE plantlets correlated with high leafTSS (Table 2). This indicated that starch stored in the leaves was consumed presumably to fulfill energy demands of growing meristems (sinks). The carbohydrate status and final state of the plantlets produced by tissue culture is particularly important for in vitro plantlets to overcome the stress period during subsequent rooting and regrowth ex vitro (Piqueras et al., 1998). Maintaining the photosynthetic and carbohydrate status of in vitro hosta (Hosta tokudama L.) and broccoli (Brassica oleracea L. Italica Group) plantlets has been shown to improve ex vitro visual quality and acclimatization to the greenhouse (Wilson et al., 1998; Wilson et al., 2000).

Carbohydrate concentration of plantlets was also influenced by the position of the plantlets in the vessel. $\mathrm{FH}$ plantlets located in the front (closer to $\mathrm{CO}_{2}$ inlet) or middle of the vessel had higher root TSS and leaf starch than did FH plantlets located in the back of the vessel (closer to $\mathrm{CO}_{2}$ outlet) (Fig. 1 and 2). FM plantlets located in the middle of the vessel had higher stem TSS than did FM plantlets located in the front or back of the vessel. Similar to FH plantlets, FM plantlets in the front or middle of the vessel also had higher leaf starch than did plantlets in the back of the vessel. FL plantlets located in the middle of 
the vessel had lower stem TSS and starch than did plantlets located in the back of the vessel. Reduced carbohydrates of plantlets located in the middle of the FL vessel correlated with a $27 \%$ to $36 \%$ reduction in dry weight (data not presented). Leaf TSS was higher in FL plantlets located in the back of the vessel as compared to the front of the vessel. Such differences among treatments and spatial variations in each treatment are perhaps caused by the variations in $\mathrm{CO}_{2}$ concentration and air current speed. The $\mathrm{CO}_{2}$ concentration within the FL vessel was reported to be $200 \mu \mathrm{mol} \cdot \mathrm{mol}^{-1}$ lower at the air outlet than at the air inlet (Heo et al., 2000). Regardless of the reduced carbohydrate content in $\mathrm{FH}$ and FM plantlets located near the $\mathrm{CO}_{2}$ outlet, plant growth remained uniform. Visualization experiments within the FH culture vessel showed uniform spatial distributions of air currents and $\mathrm{CO}_{2}$ concentration which, subsequently, increased plant growth uniformly (Heo et al., 2000), but the carbohydrate status of the plantlets was not necessarily uniform in this treatment. Further investigations are necessary to determine exvitro growth of plantlets produced in different locations in the vessel and under different ventilation rates.

\section{Literature cited}

Boersig, M.R. and F.B. Negm. 1985. Prevention of sucrose inversion during preparation of HPLC samples. HortScience 20:1054-1056.

Deng, R. and D.J. Donnelly. 1993. In vitro hardening of red raspberry by $\mathrm{CO}_{2}$ enrichment and reduced medium sucrose concentration. HortScience 28:10481051 .
Fujiwara, K., T. Kozai, Y. and Watanabe. 1987. Fundamental studies on environments in plant tissue culture vessels. Measurements of carbon dioxide gas concentration in stoppered vessels containing tissue cultured plantlets and estimates of net photosynthetic rates of the plantlets. J. Agr. Meteorol. Japan. 43:21-30 (in Japanese with English summary and captions).

Fujiwara, K., T. Kozai, and I. Watanabe. 1988. Development of a photoautotrophic tissue culture system for shoots and/or plantlets at rooting and acclimatization stages. Acta Hort. 230:153-158.

Haissig, B.E. and R.E. Dickson. 1979. Starch measurement in plant tissue using enzymatic hydrolysis. Physiol. Plant. 47:151-157.

Heo, J. and T. Kozai. 1999. Forced ventilation micropropagation system for enhancing photosynthesis, growth and development of plantlets and its application to sweetpotato. Environ. Control in Biol. 37:83-92.

Heo, J., S.B. Wilson, and T. Kozai. 2000. A forced ventilation micropropagation system for production of photoautotrophic sweetpotato plug plantlets in a scaled-up culture vessel: I. Growth and Uniformity. HortTechnology 11(1):90-94.

Kozai, T., K. Fujiwara, and I. Watanabe. 1986. Fundamental studies on environments in plant tissue culture vessels. II. Effects of stoppers and vessels on gas exchange rates between inside and outside of vessels closed with stoppers. J. Agr. Meteorol. 42:119-127.

Kozai, T. and Y. Iwanami. 1988. Effects of $\mathrm{CO}_{2}$ enrichment and sucrose concentration under high photon fluxes on plantlets growth of carnation (Dianthus caryophyllus L.) in tissue culture during the preparation stage. J. Jpn. Soc. Hort. Sci. 57:279-288.

Kozai, T., Y. Koyama, and I. Watanabe. 1988. Multiplication of potato plantlets in vivo with sugar free medium under high photosynthetic photon flux. Acta Hort. 230:121-127.

Kozai, T., C. Kubota, and B.R. Jeong. 1997. Environmental control for the largescale production of plants through in vitro techniques. Plant Cell, Tissue Organ Cult. 51:49-56.

Miller, W.B. and R.W. Langhans. 1989. Carbohydrate changes of Easter Lilies during growth in normal and reduced irradiance environments. J. Amer. Soc. Hort. Sci. 114:310-315.

Murashige, T. and F. Skoog. 1962. A revised medium for rapid growth and bioassays with tobacco tissue cultures. Physiol. Plant. 15:473-497.

Piqueras, A., J.M. van Huylenbroeck, B.H. Han, and P.C. Debergh. 1998. Carbohydrate partitioning and metabolism during acclimatization of micropropagated Calathea. Plant Growth Regulation. 26:25-31.

Van Huylenbroeck, J.M., A. Piqueras, and P.C. Debergh. 1998. Photosynthesis and carbon metabolism in leaves formed prior and during ex vitro acclimatization of micropropagated plants. Plant Science. 134:21-30.

Wilson, S.B., N.C. Rajapakse, and R.E. Young. 1998. Responses of broccoli seedlings to light quality during low-temperature storage in vitro. II. Sugar content and photosynthetic efficiency. HortScience 33:1258-1261.

Wilson, S.B., N.C. Rajapakse, and R.E. Young. 2000. Carbohydrate status and post storage recovery of micropropagated hosta plantlets stored at varying temperatures in light or darkness. Acta Hort. (in press).

Zobayed, S.M.A., C. Kubota, and T. Kozai. 1999. Development of a forced ventilation micropropagation system for large-scale photoautotrophic culture and its utilization in sweet potato. In Vitro Cellular Dev. Biol.-Plant. 35:350-355. 